\title{
Studies on Viral-Induced Anemia in Horses Infected with Equine Infectious Anemia Virus
}

\author{
Hiroshi SENTSUI, and Yuji KONO \\ Second Research Division, National Institute of Animal Health, 3-1-1 Kannondai, Tsukuba-shi Ibaraki 305, Japan
}

(Received 3 February 1987/Accepted 20 November 1987)

ABSTRACT. The mechanism of anemia of equine infectious anemia (EIA) was investigated using
erythrocytes (RBCs) from five horses experimentally inoculated with the virus. The RBCs collected
from these horses in pyrexial and viremic periods were found to have high titers of EIA virus. These
RBCs were liable to be lysed in fresh guinea pig serum and to be phagocytized by cultivated horse
leukocytes comparing with those collected in the preinoculation and incubation periods. All horses
showed decrease in RBC counts followed by the first typical fever after inoculation though some of
them did not have detectable antibody by virus neutralization, hemagglutination inhibition and
immunodiffusion tests in these periods. Complement activity of horse sera were decreased in some
degree after the peak of pyrexia. So it seems to be concluded that the interaction of RBCs with EIA
virus, complement attraction on them without antiviral antibody and successive hemolysis and
phagocytosis of them play important roles in the induction of anemia in the infected horses. However,
complement coated RBCs were hardly detected by immunofluorescent test in the peripheral blood,
probably because they were destructed and eliminated continuously from the circulatory system
without accumulation.-KEY woRDs: equine, erythrocyte, horse, infectious anemia, sideroleukocyte.
- Kpn. J. Vet. Sci. 50(2): 303-311, 1988

Equine infectious anemia (EIA) is an acute or chronic viral disease of horses and which is primary characterized by intermittent fever with viremia and anemia $[4,7]$. The pathogenesis of the anemia has not been completely elucidated. Bone marrow suppression $[12,26]$ and destruction of erythrocytes (RBCs) $[13,15,16]$ are considered as principal causes of anemia. The destruction of RBCs was documented by the decrease of their life span $[13,15]$, and complement attachment on them and successive their osmotic fragility [11] were supposed to be one of the causes of it. However, the mechanism of complement binding to RBCs has not yet been elucidated. On the other hand, since EIA virus possesses a hemagglutinin to horse RBCs [21], it has been suggested that the virus can attach on RBCs in horse body. In the in vitro experiment system, it was indicated that hemagglutinin adsorbed RBCs could attract complement [23] and some of them were lysed or phagocytized by cultivated leukocytes $[23,24]$. So, we tried to determine whether these phenomena were indeed occurring in EIA virus infected horses and whether they were working as causes of the anemia. In this report, using RBCs collected from EIA virus-infected horses in progress of disease, virus and complement attachment on RBCs, hemolysis under guinea pig complement and phagocytosis by cultivated horse leukocytes were examined. The relation of these results and the symptoms of infected horses was also discussed.

\section{MATERIALS AND METHODS}

Experimental horses and samplings: Five horses were experimentally infected with Wyoming strain of EIA virus [10]. The virus material, was lyophilized serum collected from a horse infected with the strain at the 
Table 1. Inoculated virus dose and clinical symptoms of experimental horses

\begin{tabular}{cccccc}
\hline $\begin{array}{c}\text { Horse } \\
\text { No. }\end{array}$ & Breed & Sex & $\begin{array}{c}\text { Inoculation } \\
\left(\log \text { TCID }_{50} / \text { S.C. }\right)\end{array}$ & $\begin{array}{c}\text { Incubation } \\
\text { (days) }\end{array}$ & $\begin{array}{c}\text { Clinical } \\
\text { symptom }\end{array}$ \\
\hline H-616 & Arab & Male & 3.75 & 13 & Acute \\
H-617 & Arab & Male & 5.75 & 8 & Acute \\
H-618 & Pony & Female & 4.75 & 7 & Acute \\
H-619 & Pony & Female & 3.75 & 13 & Chronic \\
H-620 & Pony & Female & 2.75 & 21 & Chronic \\
\hline
\end{tabular}

first pyrexia and contained about $10^{5.75} \mathrm{TCID}_{50} / 0.1 \mathrm{~m} l$ of virus infectivity titer. Details about horses and inoculated virus titers are shown in Table 1. Body temperature was taken twice a day over the experimental period. Hematological examinations including the test for sideroleukocytes were carried out at least once a week when their body temperature was normal and every day during feverish period using the ethylene diamine tetraacetic acid treated blood taken from the jugular vein. Total white blood cells and RBC counts, hemoglobin value, and hematocrite value were determined using Coulter Counter (Model Zf: Coulter electronic Inc., Hialeh, Fla., USA). Sideroleukocytes were observed using the method reported by Ishii et al. [6]. Virus neutralization (VN) [10], hemagglutination inhibition (HI) [21] and immunodiffusion (ID) [14] tests were carried out as described previously. The horses which showed chronic symptoms after onset of the disease were inoculated intramuscularly from 62 days after infection with five consecutive daily dose of $0.2 \mathrm{mg}$ of dexamethasone (Corson P; Takeda Pharmaceutical Co., Japan) [8] per Kilogram of body weight.

Virus titration and observation of complement coated erythrocytes: Erythrocytes obtained from heparinized jugular vein blood were washed five times each with 40 volumes of phosphate buffered saline solution (PBS). Washed RBCs were suspended at a $10 \%$ concentration in Eagle minimum essential medium (MEM) and lysed by freeze-thawing. Fresh serum was obtained as described in the following section. Infectivity titration of these samples were carried out by the end point method in tube cultures of normal horse leukocytes [9].

Detection of complement on RBCs were carried out by immunofluorescent test using FITC conjugated anti-horse complement rabbit serum as reported previously [23]. Briefly, $1 \times 10^{7}$ of RBCs in heparinized blood were washed twice with PBS and suspended in $0.2 \mathrm{~m} l$ of FITC conjugated anti-horse complement rabbit serum for 30 min in ice water. The RBCs were washed again twice with PBS, resuspended in PBS and observed with a fluorescence microscope (Photomicroscope III; Carl Zeiss, West Germany).

Titration of complement activity in experimental horse serum: Blood collected serially from experimental horses were kept at $37^{\circ} \mathrm{C}$ for $30 \mathrm{~min}$. The sera were separated from the blood clot after centrifugation at $1,000 \times \mathrm{g}$ for $30 \mathrm{~min}$ at $4^{\circ} \mathrm{C}$, and stored at $-80^{\circ} \mathrm{C}$. All stocked serum samples were tested for the complement activity simultaneously using the same sensitized sheep RBCs with rabbit hemolysin under the same condition. Zero point two $\mathrm{m} l$ of diluted serum was mixed with $0.2 \mathrm{~m} l$ of veronal buffered saline solution containing divalent cations (VBS) in glass tubes $(1.3 \times 10 \mathrm{~cm})$ and then $0.2 \mathrm{~m} l$ of a $1.5 \%$ sensitized sheep RBC suspension in VBS was added. After incubation at $37^{\circ} \mathrm{C}$ for $2 \mathrm{hr}$, the mixture 
were centrifuged and the supernatant was removed. Sedimented cells in each tube were lysed adding $0.6 \mathrm{~m} l$ of distilled water. The degree of hemolysis was calculated from the hemoglobin value of the sedimented RBCs which determined by extinction measurements at a wave length of $540 \mathrm{~nm}$ using a digital double beam proyrammable multi-wavelength spectrophotometer (UVIDEC-1M; Nihon Bunkou Co., Tokyo, Japan). Percent of hemolysis was read from a standard curve drown from completely lysed RBCs at different concentrations. The reciprocal of the serum dilution showing $50 \%$ hemolysis was considered as the complement activity titer.

Phagocytosis of RBCs from infected horses by cultivated leukocytes: Leukocytes obtained from a normal horse were cultivated in glass bottles at $37^{\circ} \mathrm{C}$ for $24 \mathrm{hr}$, and adherent cells were collected and suspended at a concentration of $5.0 \times 10^{6} / \mathrm{ml}$ in an assay medium which consisted of $95 \%$ Eagle MEM and 5\% inactivated horse serum. The leukocyte suspension in an amount of $0.5 \mathrm{~m} l$ was added to each well (16mm in diameter) of a 24-well multiwell plate (FB-16-24-TC; Limbro, Hamden, Conn., USA) and cultivated at $37^{\circ} \mathrm{C}$ in a humidified $5 \% \mathrm{CO}_{2}-95 \%$ air incubator. Erythrocytes which collected from experimental horses and radiolabeled with ${ }^{51} \mathrm{Cr}$ were added at the concentration of $1 \times 10^{7} /$ well to cultivated leukocytes. After incubation at $37^{\circ} \mathrm{C}$ for 2 hours, free RBCs were lysed and removed. Phagocytized RBCs were calculated from the radioactivity of leukocytes determined in a gamma counter (Beckman gamma 5500 counter system; Beckman Instruments Inc., Fullerton, Calif., USA). Details of leukocytes cultivation, assay medium, radiolabeling of RBCs and procedures of phagocytosis assay used in this study were reported previously [24].

Erythrocyte lysis by complement: Horse RBCs obtained from heparinized jugular vein blood were washed twice with PBS and adjusted as a $1.5 \%$ suspension in PBS. Zero point two $\mathrm{m} l$ of the RBC suspension was mixed with $0.4 \mathrm{~m} l$ of undiluted fresh horse serum or diluted fresh guinea pig serum containing 8 units of complement activity. After placing at $37^{\circ} \mathrm{C}$ for $90 \mathrm{~min}$, nonlysed cells were sedimented by centrifugation. The degree of hemolysis was determined by the detection of hemoglobin in the supernatant by extinction measurement at a wave range of $540 \mathrm{~nm}$.

Variation of hemoglobin levels in plasma: Heparinized blood collected from jugular vein was immediately centrifuged at $1,000 \times \mathrm{g}$ for $20 \mathrm{~min}$ and the resulting plasma layer was collected. Turbidity in plasma by lipemia was removed by mixing equal volume of ethyl ether for $5 \mathrm{~min}$ and centrifugation at $500 \times \mathrm{g}$ for $10 \mathrm{~min}$. Variation of hemoglobin levels in the plasma was determined by extinction measurement at a wave length of $540 \mathrm{~nm}$.

\section{RESULTS}

All the five horses showed typical fever after inoculation. Two horses, H616 and H617 of them, were acute cases and died at the first pyrexia. Antibody to the virus was not detected by $\mathrm{VN}, \mathrm{HI}$ and ID tests. Another horse, H618, was also an acute case and died after its body temperature rose to about $40^{\circ} \mathrm{C}$ and continued for two weeks. Antibodies were detected by $\mathrm{HI}$ and ID tests 15 days after inoculation but VN antibody was not found for life. The other two horses, H619 and H620, showed chronic symptoms after onset of the disease and the former manifested recurrent fever 48 days after infection, but the later continued to maintain normal body temperature. Both horses were induced typical febrile responses by inoculation intramuscularly with dexamethasone.

Their body temperature, RBC numbers, hemolytic complement activity titer in 
serum, phagocytosis of RBCs by cultivated leukocytes, ratio of RBC lysis under 8 units of guinea pig complement, virus infective titers in serum and on RBCs, sideroleukocyte appearance and VN, HI and ID antibody titers were fluctuated accompanied with progress of the disease. As to these five experimental horses, they are compared between the preinoculation periods and the first feverish periods (Table 2). Especially as to the three horses (H617, H618 and H619) of them, their variations accompanied with the lapse of time are illustrated (Figs. 1, 2 and 3).

The virus began to increase in the serum and on RBCs accompanied with the rise in body temperature and was detectable during the first pyrexial period in all infected horses. Infective titers of virus in serum and on RBCs were more than $10^{6.00} \mathrm{TCID}_{50} /$ $0.1 \mathrm{~m} l$ and $10^{3.00} \mathrm{TCID}_{50} / 0.1 \mathrm{~m} l$ respectively in two acute cases of horses when their body temperatures were more than $41^{\circ} \mathrm{C}$. On the other hand, in the case of H618, whose body temperature rose to about $40^{\circ} \mathrm{C}$ and continued for two weeks, virus titer on RBCs increased gradually from $10^{1.00} \mathrm{TCID}_{50}$ ' $0.1 \mathrm{~m} l$ on the first feverish day to $10^{4.00} \mathrm{TCID}_{50} / 0.1 \mathrm{~m} l$ on the 14 th day, though virus titer in serum was maintained between $10^{3.25}$ and $10^{5.00} \mathrm{TCID}_{50} / 0.1 \mathrm{~m} l$ during the feverish days. In two chronic cases of horses, the virus titers in the serum and on $\mathrm{RBCs}$ decreased along with the fall in body temperature and it was often undetectable when body temperature became normal.

Erythrocyte counts were reduced correlated with the increase of body temperature

Table 2. Clinical and immunological responses of five horses experimentally infected with EIA virus in the first feverish period

\begin{tabular}{|c|c|c|c|c|c|c|}
\hline & \multirow{2}{*}{ Time period } & \multicolumn{5}{|c|}{ Horse No. } \\
\hline & & 616 & 617 & 618 & 619 & 620 \\
\hline First fever (Days p.i.) & & $13-20$ & $8-13$ & $7-29$ & $13-17$ & $21-23$ \\
\hline Temperature $\left({ }^{\circ} \mathrm{C}\right)$ & $\left\{\begin{array}{l}\text { Pre }^{\mathrm{a})} \\
\text { Feverish }^{\mathrm{b})}\end{array}\right.$ & $\begin{array}{l}37.3 \\
41.3\end{array}$ & $\begin{array}{l}37.5 \\
41.6\end{array}$ & $\begin{array}{l}37.9 \\
40.4\end{array}$ & $\begin{array}{l}37.8 \\
41.4\end{array}$ & $\begin{array}{l}37.6 \\
40.2\end{array}$ \\
\hline $\mathrm{RBC}\left(\times 10^{6} / \mathrm{mm}^{3}\right)$ & $\left\{\begin{array}{l}\text { Pre }^{\mathrm{a})} \\
\text { Feverish }^{\mathrm{c})}\end{array}\right.$ & $\begin{array}{l}845 \\
674\end{array}$ & $\begin{array}{l}818 \\
666\end{array}$ & $\begin{array}{l}713 \\
551\end{array}$ & $\begin{array}{l}845 \\
724\end{array}$ & $\begin{array}{l}756 \\
741\end{array}$ \\
\hline Antibody Feverish & $\left\{\begin{array}{l}1 \mathrm{D}^{\mathrm{d})} \\
\mathrm{HI}^{\mathrm{c})} \\
\mathrm{VN}^{\mathrm{f})}\end{array}\right.$ & $\begin{array}{l}- \\
- \\
-\end{array}$ & $\begin{array}{l}- \\
- \\
-\end{array}$ & $\begin{array}{l}-\sim+g) \\
-\sim+g) \\
-\end{array}$ & $\begin{array}{l}+ \\
- \\
-\end{array}$ & $\begin{array}{l}+ \\
+ \\
-\end{array}$ \\
\hline Hemolytic complement & $\left\{\begin{array}{l}\text { Pre }^{\text {a) }} \\
\text { Feverish }^{\mathrm{c})}\end{array}\right.$ & $\begin{array}{l}9.14 \\
6.20\end{array}$ & $\begin{array}{l}8.80 \\
6.20\end{array}$ & $\begin{array}{l}9.14 \\
4.00\end{array}$ & $\begin{array}{l}12.80 \\
8.00\end{array}$ & $\begin{array}{l}8.00 \\
8.00\end{array}$ \\
\hline RBC lysis $(\%)$ & $\left\{\begin{array}{l}\text { Pre }^{a)} \\
\left.\text { Feverish }^{b}\right)\end{array}\right.$ & $\begin{array}{l}52.6 \\
85.0\end{array}$ & $\begin{array}{l}12.8 \\
22.4\end{array}$ & $\begin{array}{l}10.4 \\
18.0\end{array}$ & $\begin{array}{l}8.8 \\
20.2\end{array}$ & $\begin{array}{l}13.0 \\
11.8\end{array}$ \\
\hline RBC Phagocytosis & $\left\{\begin{array}{l}\text { Pre } \\
\text { Feverish }^{\mathrm{b})}\end{array}\right.$ & $\begin{array}{l}1.43 \\
1.93\end{array}$ & $\begin{array}{l}1.25 \\
1.91\end{array}$ & $\begin{array}{l}1.16 \\
1.88\end{array}$ & $\begin{array}{l}1.16 \\
2.11\end{array}$ & $\begin{array}{l}1.28 \\
1.75\end{array}$ \\
\hline
\end{tabular}
a) Average of 4 days before infection.
b) The highest in the feverish period.
c) The lowest in the feverish period.
d) Immunodiffusion.
e) Hemagglutinin inhibition.
f) Virus neutralization.
g) Detected from 15 days after infection. 


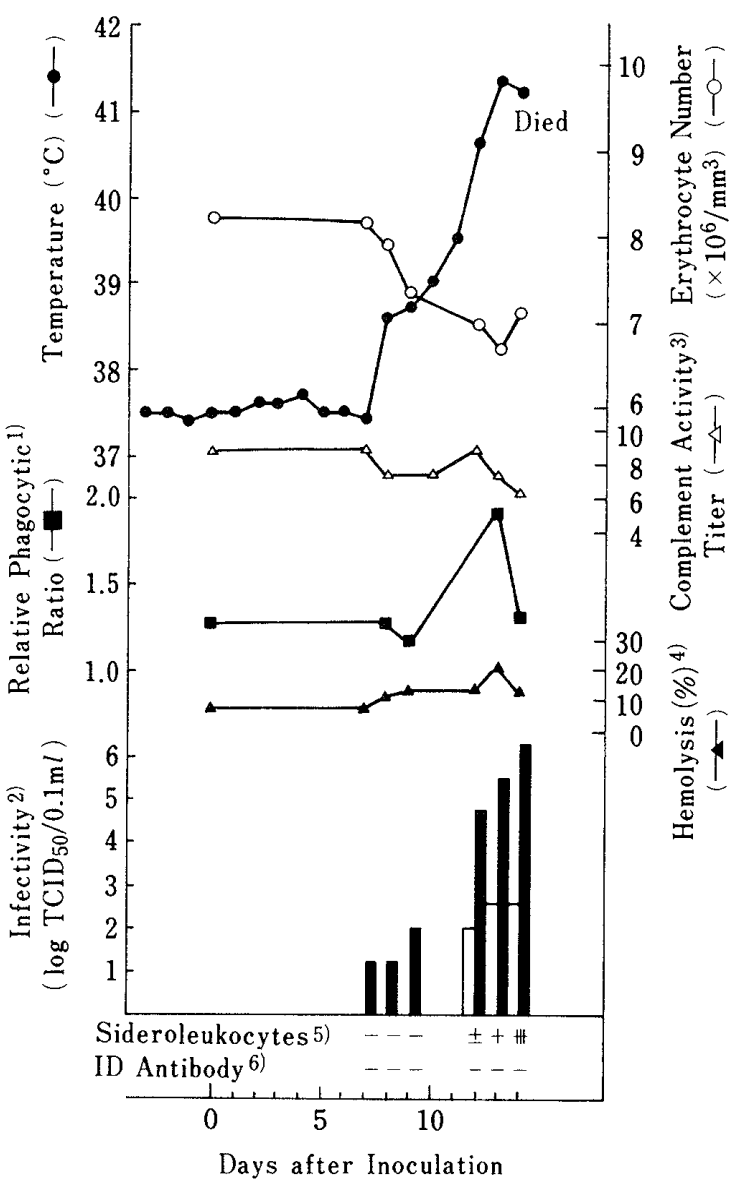

Fig. 1. Clinical and immunological responses of Horse 617 (acute case). 1) Ratio of phagocytosis of infected horse erythrocytes and control horse erythrocytes (Relative phagocytic ratio). 2) Infectivity of erythrocytes (open bar) and serum (closed bar) shown as histogram in terms of $\log \mathrm{TCID}_{50}$ ' $0.1 \mathrm{~m} l$. 3) Reciprocal of serum dilution induced $50 \%$ hemolysis of sensitized sheep erythrocytes. 4) Percentage of hemolysis of erythrocytes under 8 units of guinea pig complement. 5) Number of sideroleukocytes found among about 10,000 leukocytes. - : zero, $+: 1,+: 2-5,+: 6-20$, \#t: $>21.6)$ Immunodiffusion antibody; $-:$ negative, + : curved faint line, $\#$ : line appeared, $\#$ : clear line appeared. Antibody to EIA virus was not detected by hemagglutination inhibition and virus neutralization tests for life.

in all infected horses. However, as far as the observation by immunofluorescein test with anti-horse complement rabbit serum, few of RBCs were coated with complement in the blood collected from jugular vein during the pyrexia. The ratio of positive RBCs was at most $0.1 \%$ including those of which surface

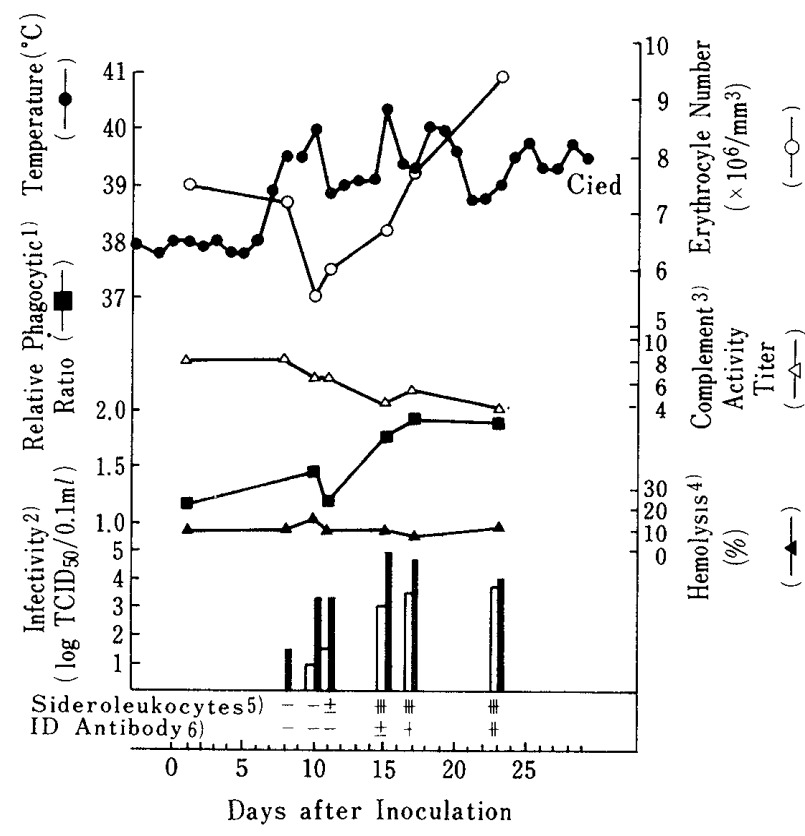

Fig. 2. Clinical and immunological responses of horse 618 (acute case). See footnotes 1)-6) of Fig. 1. Antibody to EIA virus was detected from 15 days after infection by hemagglutination inhibition test but not detected by virus neutralization test for life.

were stained partially or sectionally, even when the body temperature increased to more than $41^{\circ} \mathrm{C}$.

Sideroleukocytes appeared in the blood from jugular vein of the four experimentally infected horses approximately from the second day of continued pyrexial days and increased in numbers, and had been detectable until several days after the fall in body temperature. However, in the case of $\mathrm{H} 620$, only a small numbers of sideroleukocytes had been detected even just after the peak of pyrexia.

Since the phagocytizing activity of the leukocytes from a healthy horse which cultivated for $24 \mathrm{hr}$ was changeable because of unknown factors of cultivation, it was difficult to prepare a steady condition of leukocyte culture for phagocytosis assay. Ratio of phagocytized RBCs from infected horses was less than $2 \%$ and these from a control healthy horse fluctuated between 0.25 and $0.82 \%$. Therefore, numbers of 


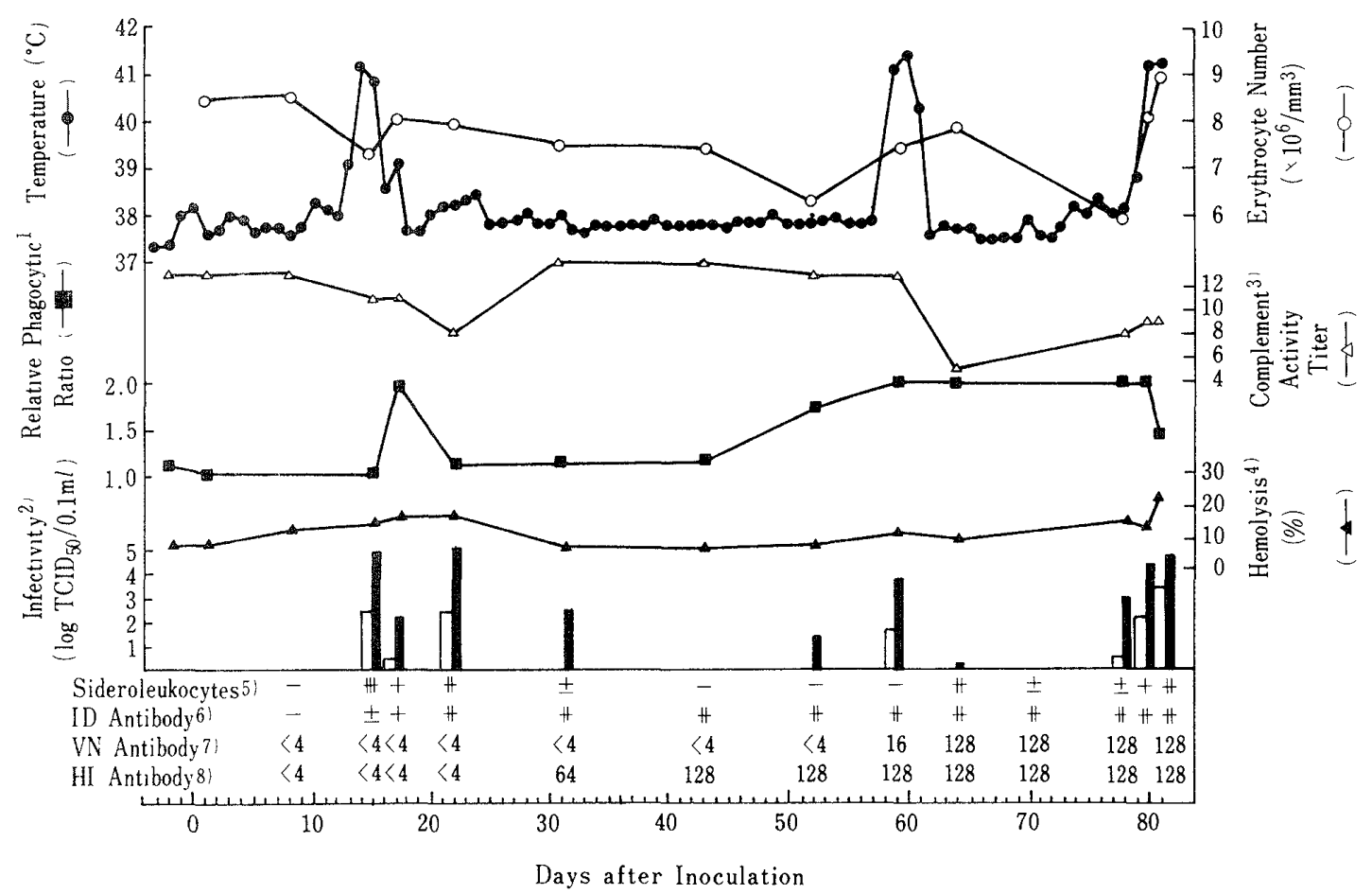

Fig. 3. Clinical and immunological responses of horse 619 (chronic case). See footnotes 1)-6) of Fig. 1. 7) Neutralizing antibody titer. 8) Hemagglutination inhibition antibody titer.

phagocytized RBCs from a infected horse and a control healthy horse were calculated respectively and compared in parallel in every phagocytosis assay. The ratio of them (relative phagocytic ratio) was used as an index of phagocytized RBCs from experimental horses. Relative phagocytic ratio which rose accompanied with the rise of body temperature and virus titers on RBCs, indicated approximately 2.00 on feverish days in acute cases of the horses. In chronic cases of the horses, it rose not only in feverish period, but also sometimes even in the intervals of recurrence though their body temperatures were normal.

About $50 \%$ of $\mathrm{RBCs}$ from $\mathrm{H} 616$ and $8-15 \%$ of those from other horses were lysed respectively after $90 \mathrm{~min}$ incubation at $37^{\circ} \mathrm{C}$ with 8 units of guinea pig complement as they were collected before infection. In the cases of H616 and H617, which showed acute forms of symptoms, the degree of $\mathrm{RBC}$ lysis increased with the rise of their body temperatures and indicated about $75 \%$ and $22 \%$ respectively in the last stage of pyrexial period. However, in the case of other three horses, the degree of their RBC lysis was not increased obviously and did not have significant relation with their symptoms.

As horse RBCs were incubated with fresh horse serum instead of guinea pig serum under the same condition, hemolysis was scarcely observed even when undiluted horse serum was subjected.

Complement activity titers of sera were different in each horse and which were between 6 to 18 when assayed using sensitized sheep RBCs. However, the titer of each horse serum was approximately stable until the beginning of pyrexial period. In the cases of three horses which showed acute forms, the titer decrease to some degree accompanied with the rise of body temperature. In the case of H619, which showed chronic symptoms, decreased complement activity was recovered about 10 days after the pyrexial period. However, in the case of 
H620, which also showed a chronic form, variation of complement activity titer was not clear and the relationship with the symptoms of the disease was not evident. It was observed that sera of every experimental horses turned untransparent during and after the period of pyrexia probably because of lipemia.

Variation of hemoglobin levels was not observed in the plasma collected serially from the five experimentally infected horses before, during and after the pyrexia.

\section{DISCUSSION}

All the five horses showed the typical symptoms of EIA. Three horses were acute forms and two horses were chronic forms. All of them showed decrease in RBC count followed by typical fever after inoculation with EIA virus. Some horses showed increase in RBC counts after the stage of fever crisis probably due to concentration of RBCs because of dehydration caused by high body temperature.

Since the decline of iron transfer from bone marrow to $\mathrm{RBCs}[17,18]$ and the atrophy of the hematopoietic tissue were observed $[12,26]$ in the febrile stage in EIA virus infected horses, the hypofunction of hematopoiesis in bone marrow and such organs is supposed to be one of the causes of anemia. On the other hand, since complement attachment on RBCs and resultant decrease of RBC life span [11], appearance of auto-antibodies against RBCs [19], and intravascular hemolysis [13] in and around the febrile stage were also reported, intravascular destruction of RBCs has been supposed to be important in the occurrence of the anemia. Present experiments were focused on the interaction between virus hemagglutinin and RBCs and consequential their reactions. Essentially, almost the same results were obtained from these experimentally EIA virus infected horses by several tests which were done to elucidate a mechanism of anemia. So, anemia of these horses was supposed to be caused by the identical or resemble mechanisms, though each horse showed different clinical symptoms.

Both hemolytic ratio and relative phagocytic ratio rose accompanied with the rise of body temperature, viremia and attachment of viruses on RBCs. These results suggest that several reactions which followed interaction of intact virus or hemagglutinin subunits with RBCs works as one of the causes of anemia. However, appearance of the complement attached RBCs and both hemolysis and phagocytosis of RBCs in this study were not so obvious as those observed in our previous in vitro experiments [23, 24]. In those in vitro experiments, RBCs were treated with high concentration of virus. On the other hand, in the infected horse body, virus propagation, virus and complement attachment on RBCs, their lysis and phagocytosis by leukocytes were probably occurring continuously. These RBCs would be under the clearance control and be eliminated from the circulating blood without accumulation. Accumulation of a large quantity of sideroleukocytes which seemed to be eliminated from the peripheral blood had been observed in spleen $[5,25]$.

It was reported that auto-antibodies against RBCs appear and bind to RBCs in horses infected with EIA virus [19]. In the present experiments, erythrocyte sedimentation in the heparinized jugular vein blood was increased during the pyrexia in some horses, and such a phenomenon suggested that the RBCs might be agglutinated with some immunoglobulin. However, as far as the observation by direct immunofluorescein test with anti-horse immunoglobulin rabbit serum (E. Y Lab. INC., San Mateo, Calif., USA), the RBCs with fluorescence were hardly detected in the blood even in the feverish periods. 
Studies on the auto-antibody and the role of the auto-antibody reaction in the cause of anemia still remain for future investigations.

It was reported that intravascular hemolysis occurs in horses exposed to EIA virus [13] and our previous study also indicated that such hemolysis is likely [23]. However, results of the present study demonstrated that such a hemolysis was not obvious and seem to play minor role as a cause of anemia. On the other hand, indirect hemolysis mediated by phagocytes would be efficient. Our previous study demonstrated that the phagocytosis by macrophage was induced by small quantity of hemagglutinin on RBCs [24]. During the study, it was also observed that contaminated neutrocytes ingested affected RBCs. Neutrocytes are known to have receptors against immunoglobulin and third complement component $[1,3]$, rich in phagocytizing activity and account for almost half of circulating leukocytes. A large amount of sideroleukocytes which originated from macrophages and neutrocytes, had been found in spleen [5, $25,26]$. So, their role in the phagocytosis of affected RBCs would be also significant.

Decrease of $\mathrm{RBC}$ numbers and appearance of sideroleukocytes were observed in and after the pyrexial period accompanied with viremia though there were no detectable antibodies by $\mathrm{CF}, \mathrm{HI}$ and $\mathrm{VN}$ tests. Hemagglutinin adsorbed RBCs could activate complement without antiserum in the in vitro experiment [23]. These phenomena suggested that these antiviral antibodies were not necessarily required in the mechanism of anemia. However, in present study, many sideroleukocytes were found in peripheral blood of a horse which manifested recurrent fever and had a high titer of $\mathrm{HI}$ antibody about in two months after infection. In our previous report, EIA virus was coexisted with $\mathrm{HI}$ antibody in the virus-infected horse [22]. Virus-antibody mixture which had lost HA activity could induce hemolysis and phagocytosis of RBCs though antibody addition did not obviously enhance the reactions $[23,24]$. So, it is supposable that virus specific immune complexes on RBCs could also attract complement. The hemolysis by complement activation seems to be induced by virus specific immune complexes on RBCs, as well as by virus mediated RBCs.

Decreased complement activity was observed in serum samples taken in the later part or at the end of active clinical disease. The phenomenon was already reported by Perryman et al. [20] using single radial immunodiffusion test. The consumption of circulating blood C3 might have been more serious than it looked in horses infected with EIA virus, since decreased complement level would be generally replenished rapidly in the system [2].

REFERENCES

1. Banks, K. L. and McGuire, T. C. 1975. Surface receptors on neutrophils and monocytes from immunodeficient and normal horses. Immunology 28: 581-588.

2. Colten, H. R. 1976. Biosynthesis of Complement. Adv. Immunology 22: 67-118.

3. Ehlenberger, A. G. and Nussenzweig, V. 1977. The role of membrane receptors for $\mathrm{C} 3 \mathrm{~b}$ and $\mathrm{C} 3 \mathrm{~d}$ in phagocytosis. J. Exp. Med. 145: 357-371.

4. Ishii, S. 1963. Equine infectious anemia or swamp fever. Adv. Vet. Sci. 8: 263-298.

5. Ishii, S. 1939. On the histo-pathological studies of equine infectious anemia in the horse. III. Observation on tissue-iron and siderocytes. Jpn. J. Vet. Sci. 1: 211-237 (in Japanese, English summary).

6. Ishii, S., Nobuto, K. and Tanaka, K. 1940. On the histo-pathological studies of infectious anemia in the horse. V. On the detection of siderocytes in the blood of vena juguralis and it's clinical diagnostic value. Jpn. J. Vet. Sci. 2: 531-557 (in Japanese, English summary).

7. Kono, Y. 1969. Viremia and immunological responses in horses infected with equine infectious anemia virus. Natl. Inst. Anim. Health Q. 9: $1-9$.

8. Kono, Y., Hirasawa, K., Fukunaga, Y. and Taniguchi, T. 1976. Recrudescence of equine 
infectious anemia by treatment with immunosuppressive drugs. Natl. Inst. Anim. Health $Q .16$ : $8-15$.

9. Kono, Y. and Kobayashi, K. 1967. Specificity of assay of equine infectious anemia virus in horse leukocyte culture. Natl. Inst. Anim. Health Q. 7: 138-144.

10. Kono, Y., Kobayashi, K. and Fukunaga, Y. 1971. Serological comparison among varioius strains of equine infectious anemia virus. Arch. Gesamte Virusforsch. 34: 202-208.

11. McGuire, T. C., Henson, J. B. and Bueger, D. 1969. Complement (C3)-coated red blood cells following infection with the virus of equine infectious anemia. J. Immunol. 103: 293-299.

12. McGuire, T. C., Henson, J. B. and Quist, S. E. 1969. Imparired bone marrow response in equine infectious anemia. Am. J. Vet. Res. 30: 2099-2104.

13. McGuire, T. C., Henson, J. B. and Quist, S. E. 1969. Viral-induced hemolysis in equine infectious anemia. Am. J. Vet. Res. 30: 2091-2097.

14. Nakajima, H. and Ushimi, C. 1971. Immunodiffusion studies of purified equine infectious anemia virus. Infec. Immun. 3: 373-377.

15. Obara, J. and Nakajima, H. 1961. Life span of $51 \mathrm{Cr}$-labeled erythrocytes in equine infectious anemia. Jpn. J. Vet. Sci. 23: 207-210.

16. Obara, J. and Nakajima, H. 1961. Iron metabolism in equine infectious anemia. V. Measurement of sites on erythrocyte destruction. Natl. Inst. Anim. Health Q. 1: 32-35.

17. Obara, J. and Nakajima, H. 1961. Iron metabolism in equine infectious anemia. VI. Organ uptake of plasma-bound iron-59. Natl. Inst. Anim. Health Q. 1: 36-40.

18. Obara, J., Sonoda, A. and Nakajima, H. 1962.
Determination of DFP32-labeled erythrocyte lifespan and plasma cholinesterase turnover rate in equine infectious anemia. Natl. Inst. Anim. Health Q. 2: 229-236.

19. Oki, Y. and Miura, Y. 1970. Characteristics and roles of red cell auto-antibodies in equine infectious anemia. Jpn. J. Vet. Sci. 32: 217-226 (in Japanese, English summary).

20. Perryman, L. E., McGuire, T. C., Banks, K. L. and Henson, J. B. 1971. Decreased C3 levels in a chronic virus infection: Equine infectious anemia. J. Immunol. 106: 1074-1078.

21. Sentsui, H. and Kono, Y. 1981. Hemagglutination by several strains of equine infectious anemia virus. Arch. Virol. 67: 75-84.

22. Sentsui, H. and Kono, Y. 1981. Hemagglutination-inhibition tests with different strains of equine infectious anemia virus. Am. J. Vet. Res. 42: 1949-1952.

23. Sentsui, H. and Kono, Y. 1987. Complement mediated hemolysis of horse erythrocytes treated with equine infectious anemia virus. Arch. Virol. 95: 53-66.

24. Sentsui, H. and Kono, Y. 1987. Phagocytosis of horse erythrocytes treated with equine infectious anemia virus. Arch. Virol. 95: 67-77.

25. Tabuchi, E., Katada, M. and Watase, H. 1960. Studies on hematological changes of visceral blood of horses infected with infectious anemia. Bull. Natl. Inst. Anim. Health 38: 47-73 (in Japanese, English summary).

26. Yamamoto, H. and Konno, S. 1967. Pathological studies on bone marrow in equine infectious anemia. I. Macroscopical findings on whole longitudinal sections of bone marrow. Natl. Inst. Anim. Health Q. 7: 40-53.

要

約

馬伝染性貧血ウイルス感染馬におけるウイルス性貧血：泉対 博・甲野雄次（家畜衛生試験場研究第 2 部） 一一馬伝染性貧血ウイルスを接種した 5 頭の馬についてウイルスと赤血球の結合, 変性赤血球への補体の結合・ 活性化，その結果生ずる溶血またはマクロファージ等による捕食について調べた。発熱，ウイルス血症を示した ときの赤血球には，ウイルスが付着しており，モルモット補体存在下で $37^{\circ} \mathrm{C} て ゙$ 接種前または潜伏期赤血球と比 べて溶血しやすく，健康馬由来培養マクロファージによって捕食されやすかった。すべての例で初回発熱の後期 及び下熱直後に赤血球数が減少したが，その時点では一部の例でゲル内沈降試験，HI 試験，中和試験によって 抗体が検出できなかった。発熱とともに血清補体活性価は低下した。 